\title{
Pensando educação: com os pés no chão, de Tania Zagury Rio de Janeiro: Bicicleta Amarela, 2018. 175 p.
}

\author{
Emanuel Lucas Batista de Melo \\ Mestre em Gestão e Práticas Educacionais - UNINOVE \\ lucas-seg@bol.com.br
}

Tania Zagury é filósofa, mestre em educação, professora-adjunta da Universidade Federal do Rio de Janeiro (UFRJ) e autora de outros 25 livros, publicados tanto no Brasil quanto no exterior. Conferencista e pesquisadora em educação, foi também articulista do jornal $A$ Tribuna (ES) e das revistas Gestão Educacional, Profissão Mestre e Psicologia Brasil, além de ter sido eleita a personalidade educacional do ano de 2014, em votação feita pela Associação Brasileira de Educação e pelo jornal Folha Dirigida, recebendo, no mesmo ano, a Comenda da Ordem em Educação.

Em seu livro Pensando educação: com os pés no chão, a autora apresenta uma série de percepções acerca da educação brasileira por meio de vários textos, resultado dos 50 anos de experiência na área. Por ter vivenciado e acompanhado tantas mudanças ocorridas na área da educação ao longo desse tempo, Zagury entende que o fracasso do ensino básico nacional não está atrelado, primordialmente, à falta de habilidade docente, mas advém de uma série de fatores sociais que culmina no desinteresse, desrespeito e indisciplina apresentados pelos alunos.

De modo geral, a autora defende que nada adiantam discursos inflamados acerca de novas teorias motivacionais ou metodológicas sem que, para isso, estejam devidamente resolvidas as questões básicas que permeiam as necessidades mínimas para que um professor possa desempenhar um bom trabalho, tais como: equiparação salarial do trabalho docente ao dos profissionais de outras áreas com o mesmo nível de qualificação, atualização docente continuada em serviço, extinção das salas de aula multisseriadas, apoio das famílias ao trabalho docente, maior rigidez e efetividade do Poder Judiciário ao tratar casos de crianças que praticam atos de incivilidade dentro e fora de sala de aula, entre outras.

Para tanto, sua obra, aqui apresentada, divide-se em três partes, além de suas considerações finais. Na primeira delas, denominada Educação sem alivios, nem retoque, Zagury traz à tona alguns dos principais problemas vivenciados pelo ensino básico público, sendo que o 


\section{Dialogia}

MELO, Emanuel Lucas Batista de. Pensando educação: com os pés no chão, de Tania Zagury.

próprio nome dos textos que compõem essa primeira parte, remete-nos a essa ideia, manifestando a forma ácida com que ela nomeia seus títulos, como por exemplo em "Algumas causas do fracasso na educação: cadê a qualidade? Sumiu..."; "Reforma ou remendo?" e "Um profissional mais que pressionado”.

A autora assinala muitos problemas e deficiências na educação nacional, tais como a dificuldade de leitura e interpretação textual pelos alunos, a metodologia inadequada, a desmotivação de discentes e docentes e a forma de gestão das unidades escolares. Entretanto, a maior parte desses apontamentos provém de "achismos", que nem sempre são resultados de pesquisas comprováveis cientificamente. Em suma, Zagury defende que, para a superação imediata de todos esses problemas, seria necessária uma continuidade nas experiências e projetos pedagógicos - de modo que houvesse tempo hábil para que se confirmasse sua efetividade ou não -, um acompanhamento e avaliação sistemática desses processos e, por fim, a análise dos resultados obtidos, que permitiriam prorrogar ou cancelar esses projetos.

Em Os modismos em educação, segunda parte do livro, deparamo-nos com textos que abordam assuntos polêmicos e que, de certo modo, constituem os principais tabus presentes na área. No texto "Evasão: um outro ângulo", por exemplo, Zagury afirma que o grande responsável pelo abandono dos professores da docência não se deve à baixa remuneração, conforme a maioria dos “entendidos” provavelmente alegaria, mas, sim, às más condições de trabalho (indisciplina, desrespeito e desinteresse por parte dos alunos), que, sem dúvida alguma, se agravaram significantemente com o Sistema de Ciclos com Progressão Continuada.

Outros textos dessa seção do livro compartilham do mesmo princípio. Em "Aqui tudo se compra", "Ao futuro de nossos filhos", "O preço da impunidade" e "Os clássicos da tecnologia", tudo é abordado, pela autora, de forma polêmica e direta, o que, para alguns, pode parecer excesso de conservadorismo. Essa impressão se reflete ainda mais no texto "Militarizar escolas?", onde a educadora não chega a propor que as instituições escolares sejam administradas por forças militares, mas demonstra que o salto qualitativo de algumas escolas militarizadas no estado de Goiás não pode ser desprezado. O que não deve continuar, segundo ela, é o clima impróprio e inseguro que os professores são obrigados a enfrentar diariamente.

Por fim, a última parte do livro, intitulada Repensando conceitos, Zagury discute vários assuntos por meio de um viés menos ortodoxo. Em "O temido TDAH”, "Nem tudo é bullying", “Autoestima e limites", "Meritocracia e pais nas escolas" são abordadas concepções que tentam desmistificar as temáticas representadas em cada um desses títulos. O destaque fica com o texto "A gestão da escola moderna", onde ela afirma que gerir uma escola moderna é mais simples do 
que a maioria das pessoas imagina, o que não necessariamente signifique que seja fácil. A autora relata, por exemplo, que o "gestor de seus sonhos" seria aquele que, cujos alunos, ao final dos ensinos fundamental I e II, tivessem - tão somente - as competências e habilidades previstas no currículo. E isso, segundo ela, é perfeitamente possível, mediante planejamento, cooperação e dedicação.

$\mathrm{Na}$ conclusão, denominada Como ficamos, texto dotado de certo lirismo, fica clara a intenção da escritora: um ensino público de qualidade a todos os brasileiros. O que a difere das demais pessoas que pesquisam/escrevem sobre o assunto é sua notória objetividade, foco nos elementos e condições básicas a uma boa educação e sua crítica, um tanto quanto contundente, para vieses que apresentam possíveis soluções inovadoras, mas que, na verdade, acabam sendo utópicas, pois não se atentam no que, de fato, é primordial.

Pensando educação: com os pés no chão, de Tania Zagury, é uma boa leitura, recomendada, principalmente, a pesquisadores que trabalham com a questão da qualidade de ensino e também aos agentes da comunidade escolar (dirigentes, coordenadores pedagógicos e professores), pois aborda e destaca, de forma direta e incisiva, os principais e diversos fatores que contribuem para a baixa qualidade da educação nacional, sugerindo que só haverá uma mudança significativa nesse quadro quando todos os envolvidos (políticos, sociedade e educadores) atentarem para a sua resolução.

Recebido em: 18 mar. 2020 / Aprovado em: 13 maio 2020

\section{Cite como:}

\section{(ABNT NBR 6023:2018)}

MELO, Emanuel Lucas Batista de. Pensando educação: com os pés no chão, de Tania Zagury. Dialogia, São Paulo, n. 35, maio/ago. 2020. Resenha, p. 280-282. Disponível em: https://doi.org/10.5585/dialogia.n35.16820.

\section{American Psychological Association (APA)}

Melo, E. L. B. (2020, maio/ago.). Pensando educação: com os pés no chão, de Tania Zagury. Resenha. Dialogia, São Paulo, 35, p. 280-282. https://doi.org/10.5585/dialogia.n35.16820. 